\title{
Disruption and recovery of intangible resources during environmental crises: Longitudinal research on 'home' in post-disaster Puerto Rico
}

DOI:

10.1016/j.geoforum.2019.08.007

\section{Document Version}

Accepted author manuscript

Link to publication record in Manchester Research Explorer

Citation for published version (APA):

Sou, G., \& Webber, R. (2019). Disruption and recovery of intangible resources during environmental crises: Longitudinal research on 'home' in post-disaster Puerto Rico. Geoforum, 106, 182-192. https://doi.org/10.1016/j.geoforum.2019.08.007

Published in:

Geoforum

\section{Citing this paper}

Please note that where the full-text provided on Manchester Research Explorer is the Author Accepted Manuscript or Proof version this may differ from the final Published version. If citing, it is advised that you check and use the publisher's definitive version.

\section{General rights}

Copyright and moral rights for the publications made accessible in the Research Explorer are retained by the authors and/or other copyright owners and it is a condition of accessing publications that users recognise and abide by the legal requirements associated with these rights.

\section{Takedown policy}

If you believe that this document breaches copyright please refer to the University of Manchester's Takedown Procedures [http://man.ac.uk/04Y6Bo] or contact uml.scholarlycommunications@manchester.ac.uk providing relevant details, so we can investigate your claim.

\section{OPEN ACCESS}




\title{
Disruption and recovery of intangible resources during environmental crises: Longitudinal research on 'home' in post-disaster Puerto Rico
}

\begin{abstract}
There are many strategies and models that attempt to measure the impacts and losses from environmental crises. However, there remains a conceptual and methodological bias as assessments provide estimates of tangible and quantifiable indicators, whilst impact to intangible resources that are not easily quantifiable remain a significant oversight in disaster studies more specifically, and sustainability research more broadly. In this paper we use in-depth longitudinal qualitative data to theoretically and empirically demonstrate how intangible resources shape people's experience of so-called "natural" disasters. Building on this, we critically unpack how intangible resources facilitate household disaster recovery. We focus on home - an intangible resource - in order to explore these issues. The case study in Puerto Rico shows that the social characteristics of home are challenged, transformed, and/or exacerbated in different ways, and at different times, in post-disaster contexts. Our longitudinal approach reveals how people's feelings of belonging and attachment, alienation and detachment from home, fluctuate over time. In this way, the paper sheds light on how intangible resources are experienced temporally and spatially. The paper also reveals that the performance of actors such as the State and Nongovernmental organisations significantly shape how intangible resources such as home are transformed, and households' agency to maintain and recover such intangibles in post-disaster contexts. The analysis directly challenges the skewed and reductive hierarchies of what counts as a disaster loss. This is an innately political endeavour because it aims to develop strategic decision-making, from preparedness to recovery, that is sustainable for affected populations.
\end{abstract}

Keywords: Home, Disaster, Disaster recovery, Intangible resources, Puerto Rico, Emotional geographies

\section{Introduction:}

There are now strategies and models that attempt to comprehensively measure the impacts and losses from 'natural' disasters. Accordingly, an extensive and growing literature has emerged debating disaster impacts (e.g. Hallegatte and Przyluski, 2010, Neumayer and Barthel, 2011, Schumacher and Strobl, 2011, von Peter et al., 2012, Smith and Katz, 2013). Common approaches distinguish direct and indirect impacts. Therefore, the growing literature on sustainability has acknowledged the need for incorporating categories of social and environmental cost that are irreducible to economic terms (Elkington 2006, Bond et al., 2012, Truffer et al 2015). This is equally the case with disasters triggered by natural phenomena where the categorisation of losses has expanded to include items that are difficult to measure in financial terms: deaths and injuries, people affected ${ }^{1}$, health impacts, employment losses, and damage to the built environment, and environmental degradation (Magee et al 2016).

\footnotetext{
${ }^{1}$ People affected is terminology that is widely used within disaster impacts assessments, and refers to people who require the support of external humanitarian support because of the impacts of disaster (IFRC 2018)
} 
Despite the expansion of categories, there remains a conceptual and methodological bias in how disaster impacts are measured. That is, the tendency of disaster loss assessments to provide comprehensive estimates of tangible and quantifiable indicators. However, assessment of impacts to subjective and intangible resources that are not easily quantifiable, remain a significant oversight in disaster studies more specifically, and sustainability research more broadly. Whilst such material components are significant, this paper argues that the role of material resources in the restoration of the immaterial and intangible components of home, including place attachment and belonging, is of great significance. We build on the work of those such as Murcia (2018), Malkki (1995), Bakewell $(1994,2004)$ and Jansen and Löfving (2011) who discuss the ways that a focus only on the material aspects of home "underplays its symbolic and existential dimensions" (Murcia 2018: 1). The inclusion of intangible resources such as place attachment or a sense of home and belonging has usually been conducted in an ad hoc and under-theorised way, with little empirical evidence (Magee et al 2016). In critical heritage studies, Smith and Akagawa (2009) describe how attempts to safeguard Intangible Cultural Heritage have been viewed by some as a counter-response to the often Western or Eurocentric approach to heritage of the World Heritage Convention. In a similar vein, this paper seeks to problematise fixed categories of 'home' as purely material, building on previous work in critical home literature. In this paper, then, the term 'intangible resources' refers to the emotional and affective attributes of home, such as belonging, familiarity, and place attachment (Hammond 2004, Easethope 2010, Blunt and Dowling 2006). While we do not, however, take for granted an assumption of 'home' as always 'homely'. Rather, the focus of our analysis is on such intangible resources, as they are deeply interconnected with the material. This paper argues that the failure to account for these intangible losses can distort the nature and extent of disasters in several ways.

First, it minimises the losses experienced by the victims of disasters, and can suggest, incorrectly, that disasters that incur greater damage to tangible and insurable objects such as infrastructure and buildings are correspondingly more significant. The second misrepresentation derives from the fact that assessments of environmental impacts shape how particular agents manage future risk, as well as recovery programmes (Power, 2007). More specifically, if damage to intangible resources is excluded from damage assessments, it establishes a formal algorithm for generating hierarchies and classifications of what counts as a legitimate damage loss/impact. This suggests that the absence of the subjective experiences from the evaluations of disasters potentially skews strategic decision-making toward the preparedness and recovery of quantifiable tangible resources, in environmentally hazardous contexts. Magee et al (2016) argue that this exclusion is innately political. Private agencies and public institutions enjoy much greater power than citizens, to label what is officially measured as an impact or loss. This creates contemporary disaster risk management in which losses that do not 'count' and/or are marginalised from public policy and programmes, despite their importance for disaster-affected people.

Intangible resources generally are treated sparsely and unsystematically in disaster management costing frameworks (Gentle et al., 2001, Kousky, 2012, ECLAC, 2014). The United Nations Economic Commission for 
Latin America and the Caribbean's Handbook for Disaster Assessment (ECLAC, 2014) provide the most substantive treatment of intangible resources. Following Vecvagars (2006), it references spiritual value, historical value, symbolic value, social value, loss of heritage and loss of memorabilia. However, the Handbook focuses almost exclusively on methods for costing tangible values, which tacitly encourages assessments to ignore intangibles. We recommend that the references to intangible forms of value are taken more seriously, and use this paper to demonstrate the reasons for this. Furthermore, the assessments focus on intangible resources that are shared across whole neighbourhoods, whilst ignoring intangible resources that can only be understood at the level of the dwelling. For instance, ECLAC (2014: 116), focuses on public monuments, inscriptions, cave dwellings, groups of buildings, and archaeological sites which are of outstanding universal value from the historical, aesthetic, ethnological or anthropological point of view.

Magee et al (2016) builds on ECLAC, arguing that the concept of sense of place ought to be acknowledged in damage assessments. Yet, once more, the focus is on the neighbourhood level, rather than the intangible resources that are largely located within dwelling units, and which are heterogeneous across households. Although we recognise, as does the literature that the concept of 'home' often extends beyond the parameters of the house into the neighbourhood (Hammond 2004), we argue that the scale of the household is important to pay due attention to. We acknowledge these represent positive steps for understanding how intangible resources are impacted in the event of a 'natural' disaster. Home is nonetheless overlooked in ECLAC and other frameworks for understanding the impacts of disasters. A comprehensive and in-depth case analysis of how home is affected in the aftermath of a disaster would begin to treat the home - beyond merely the realms of the physical dwelling - as a further integral component.

Our research theoretically and empirically demonstrates how home shapes people's experience of disaster impacts. Building on this, we critically unpack how and why 'home' shapes household disaster recovery-a question that has largely been left unanswered. The existential experience of home as a universal, important reflection and source of self-identity for individuals has been established across multiple scholarly disciplines (e.g., Czikszentmihalyi \& Rochberg-Halton, 1981; Mallett, 2004; Moore, 2000; Blunt and Dowling 2006; ). Nevertheless, there is a deficient recognition and critical understanding of 'home' within research and policy on disasters, and international development more broadly. Where work has attended to understanding 'home' in post-disaster contexts, such as that of Morrice (2014) and Brun and Fàbos $(2015,2017)$, it has focused almost exclusively on those who are displaced by disasters. Our work offers a contribution to the academic literature on home in post-disaster contexts then by attending to the experiences of those who remain in their own homes following a disaster. By emphasizing the importance of 'home', we are not suggesting that material impacts and resources are unimportant. We agree that households with greater economic and material resources are more likely to carry out recovery activities more quickly and effectively than those who do not. Our point is that these material impacts are felt additionally as damage to subjective and intangible resources, understood in this paper as a sense of 'home', as outlined above. This damage or loss is, we argue, just as devastating to households as 
the material impacts. We take the position that disaster recovery must pay attention to the ways in which restoring material resources is a vital part of the restoration of intangible and emotional resources, given their importance to households. Finally, our paper argues, and empirically demonstrates, using in-depth longitudinal qualitative data that intangible and emotional resources act as important facilitators to household disaster recovery. Therefore, it is crucial social scientists play closer attention to the impacts to and recovery of such intangible resources if we are to understand how household agency unfolds in post disaster contexts.

\section{Home as an intangible resource in post-disaster contexts}

While housing is a critical concern in disaster impacts and recovery (Katz 2008; Thanurjan and Seneviratne 2009, Sou 2014, 2018), the notion of home is a recent addition to the literature (Brun and Lund 2008; ChamleeWright and Storr 2009; Hawkins and Maurer 2011). As Morrice (2013: 33) indicates, "there has been a notable absence in geographic literature concerning the connection between disasters and the concept of "home." Research on disasters and sense of home has mainly focused on refugees and internally displaced people who have been displaced or forcefully resettled from their geographical community. Work such as that of Laura Hammond (2004) examines the ways that homes are re-established by repatriated refugees in Ethiopia. Hammond's seminal book This Place Will Become Home explores the experiences of home of those displaced as a result of war and then returned to and granted land in Ethiopia. The key contribution here is to highlight the complex ways that space must be managed following displacement and return of this nature. Developing the understanding of where 'home' is deemed to be - in this case simply the soil itself is seen to be enough by the State - is vital if we are to understand how those who remain in place navigate the tricky terrain of home-making following a disaster. In these cases, it is not the dislocation from the place or home itself that is at stake, but rather the materiality of the house and the symbolic values of the home that are destabilised, destroyed and ruptured.

We find utility in several conceptualisations of home, drawing in particular on Blunt and Dowling's (2006) work on 'critical geographies of home' in their important book Home: Key Ideas in Geography. Here, three cross-cutting components to a critical geography of home are drawn. The first component - the 'material and emotional' evokes home not only as a physical location in which people reside but also as a space of emotion and belonging (Al-Ali and Koser, 2002; Blunt and Dowling, 2006; Rapport and Dawson, 1998). Home comprises of both a physical location and an emotional locus. Housing literature has developed this understanding to argue that home is more than a physical shell-home is material structure embedded with emotion, meaning, and memory (Blunt and Dowling 2006). Consequently, considering disaster impact and response, Brun and Lund (2008: 278) contend "when exploring the relationship between housing and homemaking in recovery processes, 'house' becomes something that is both material and emotional (symbolic) and at the same time an articulation of identity and power." Thus, a home is seen to provide not just shelter and location but ontological security (Somerville 1992) - a safe place that secures and underpins a sense of self-identity and agency (Dupuis and Thorns 1998). Mary Douglas argues that home "begins by bringing some space under control" (1991: 289). This 
exercise of agency and control is directly undermined by both disasters themselves and State responses to supporting recovery post-disaster. The re-establishment of both the material and emotional components of home following a disaster are therefore of equal importance. The nexus between home, power and identity is introduced here, this being the second component identified by Blunt and Dowling.

Just as Brickell notes that "there is a politics to home" (2012: 227) that it is important we do not overlook, the second component examines this nexus between power, home and identity, revealing that home is not static, materially or meaningfully, but is a process. Home and its meaning are made through the everyday activities and routines undertaken to establish and articulate home. But just as home is made, it can be "unmade" (Baxter and Brickell 2014) with consequences for meaning, ontological security, and well-being. While home-making is predicated on the agency of occupants, sometimes home is disrupted or destroyed by external forces. Domicide is one example. Porteous and Smith (2001: 12) define domicide as "the deliberate destruction of home by human agency in pursuit of specified goals, which causes suffering to the victims," including political, bureaucratic, and corporate agendas and projects. While Porteous and Smith's work is fairly limited in scope, as Nowicki argues (2014), for instance they exclude natural disasters from causes of domicide, by contrast, Blunt and Dowling (2006) suggest that the collusion of natural disasters and social injustice-as in Hurricane Katrina's aftermath in New Orleans-could be characterized as domicide. A domicide lens adds value to the analysis of home presented in this paper - as the entanglement of both material and intangible resources - and Nowicki stresses this point by arguing that "domicide provides a clear contribution to political understandings of the homespace and the multifaceted ways in which the home can be destroyed in a multitude of contexts" (2014: 786). The material and emotional destruction of the homes in which the participants in this study remained, is evident in the coping mechanisms put in place to manage this destruction on both the material and emotional levels. The desire to return to a sense of 'normalcy' (Fernandez, cited in Sutton 2001) occurs in the site of the disaster and against the political backdrop of the Hurricane and State responses, as opposed to in a migration context as Fernandez understands it. Yet the desire for this return is perhaps more potent as a result of taking place within the very homes that have been destroyed.

Given that natural disasters are social constructs with differential social impacts, marginal populations can experience home loss as domicide through uneven preparedness, response, and recovery in disaster policy. This indicates, third, that the link between home and identity is mediated by external or public social and political power. As Brun and Lund (2008: 278-9) state, home is "a contested territory: a meeting point between geopolitics and identity politics ... 'House' and 'home' are porous intersections of social relations and emotions, simultaneously public and private." The agency and privacy of home can be mitigated by dominant meanings and mores, surveillance, and government agendas. This space comes under renewed external pressure during disasters, where policies, often by necessity to distribute scarce resources, ignore marginal populations and the meanings and importance of home. 
Finally, the third - 'multi-scalar' - emphasizes the porosity of home as the personal relations it plays host to transect public and political worlds. Doreen Massey (1992: 14) elaborates that the identity of home derives "precisely from the fact that it had always in one way or another been open; constructed out of movement, communication, social relations which always stretched beyond it". A house can be a home, but home can register at different scales and sites-streets, neighborhoods, public spaces, cities, and nations, for example. Often a sense of home or meaningful dwelling involves the residential house and neighborhood simultaneously (Hawkins and Maurer 2011). The activities that make a home stretch beyond the house and incorporate the extra-domestic-neighboring, shopping, home-financing, family and friendship networks (Moss 1997; Hammond 2004). Neighborhood is often vital for making a home: literature shows that attachment to neighborhood-or place-attachment and place-identity-is often part of homemaking and provision of ontological security (Dupuis and Thorns 1998).

Importantly, the domestic scale of the home must be situated in the wider political context within which 'home' is constructed. In other words, "the home itself is intensely political both in its internal relationships and through its interfaces with the wider world over domestic, national and imperial scales" (Blunt and Dowling 2006: 142). Puerto Rico continues to be a colony of the United States - positioned within State governance but not as far as to be encompassed within the 52 States themselves (Sparrow 2017). Taking this into account, it is possible to see how State responses post-disaster are shaped by this relationship as one of unequal power dynamics. Furthermore the 'belonging' of Puerto Rico to the United States government, impacts directly and tangibly upon recovery of both material and emotional geographies of home following the hurricane. This is important to bear in mind in the analysis presented in this paper. The scale of the State is intricately linked with the scale of the house and the neighborhood. In this way, home expands beyond the parameters of the house not only in the ways that households construct their sense of belonging in relation to multiple scales (e.g. the house, the neighborhood) but also in the ways that action taken at the scale of the State materially affects the ways that households construct their belonging, as individuals are stripped of the control they are able to exercise over the space of the house (Douglas 1991).

\subsection{Case selection}

We selected the neighbourhood of Ingenio as our case site, a community of 4,415 persons across 1,529 households, situated in the Caribbean island Puerto Rico (US Census Bureau, 2018). Natural hazards such as droughts, floods and hurricanes shape the national poverty and vulnerability of Puerto Rico (EM-DAT). Since 1970, Puerto Rico has recorded 28 natural disasters - 6 in the past decade. In September 2017, the island was hit by two major hurricanes (Irma on September 7 and Maria on September 21). These, particularly Maria, caused major devastation to the fragile infrastructure and economic activity, and economic damages were estimated USD $\$ 31.5$ billion (FEMA, 2017). Puerto Rico is a territory of the United States (US) of America and its citizens are US citizens, however, it is not included in the 52 states. This means that citizens of Puerto Rico cannot vote in US elections for Congress or the Presidency, but they are subject to the US laws and regulations 
passed by these bodies. Puerto Rico's government is supported by US federal agencies, such as the Federal Emergency Management Agency (FEMA), and follows US federal procedures, some of which work less effectively for its island territories, especially those (like Puerto Rico) that rely on imported products (Nurse et al 2014).

Ingenio is a peri-urban, coastal community in Toa Baja municipality, and was extensively affected by Hurricane Maria. Ingenio lies in a floodplain of La Plata River, in an area surrounded by farmland, predominantly for sugarcane cultivation. It is 13.5 kilometres from Puerto Rico's capital, San Juan. At the time of this selection, Hurricane Maria had just hit Puerto Rico on September 21, 2017, causing major structural and water damage to the majority of houses in Ingenio. Initial conversations with residents in Ingenio suggested we had sufficient households willing to participate to approach theoretical saturation. The expectation of these residents to continue to live in the location despite the recent disaster suggested a longitudinal study was not only feasible but would also reveal the ways in which experiences of home rebuilding would change over time. $66 \%$ of Ingenio's residents live below the poverty rate and over $27 \%$ are female-headed households (US Census Bureau, 2018), which combined with the absence of an effective disaster response to Hurricane Maria.

\subsection{Data collection}

To gather rich descriptions, we opted for a qualitative study to understand residents' experiences, how recovery emerged, and the impacts and transformations of home. In order to further understand how these processes changed over time, we undertook a longitudinal approach, returning to interview each participant 5 times over the year. This enabled us to see how experiences of home post-disaster were managed and made sense of, and how these shift and change over time. Longitudinal data provides a richer insight into change over time in a way, which one-off interviews capture less effectively (Vogl et al 2018. Our collection of data in Ingenio began on $16^{\text {th }}$ October 2017 (27 days after Hurricane Maria hit) and concluded on $13^{\text {th }}$ September 2018 (nearly one year after the hurricane). Data was collected through five visits to Ingenio, which were equally spaced throughout the period of the year (table 1). We adopted a single-sited ethnographic approach which is appropriate to track contemporary phenomena within a real-life context over time (Yin 2003). We followed the lives of a group of selfselecting households (Marcus, 1995) that were invited to participate in the research. In our sample, households differed in the physical damage sustained (some houses suffered partial or total collapse and/or flooding) and demographics (e.g. number of household members; ages; gender ratio; income; number of dependents), and location within the neighborhood.

Table 1 Longitudinal approach to data collection

\begin{tabular}{|c|c|c|c|c|c|}
\hline $\begin{array}{c}\text { Time elapsed since } \\
\text { Hurricane Maria }\end{array}$ & Month 1 & Month 3 & Month 6 & Month $\mathbf{9}$ & Month 12 \\
\hline $\begin{array}{c}\text { Dates of visit to } \\
\text { field site }\end{array}$ & $16^{\text {th }}-30^{\text {th }}$ & $14^{\text {th }}-22^{\text {nd }}$ & $23^{\text {rd }}-31^{\text {st }}$ & $6^{\text {th }}-15^{\text {th }}$ June & $3^{\text {rd }}-13^{\text {th }}$ \\
& October 2017 & $\begin{array}{c}\text { December } \\
2017\end{array}$ & 2018 & $\begin{array}{c}\text { September } \\
2018\end{array}$ \\
\hline Duration of visit & 15 days & 9 days & 9 days & 10 days & 11 days \\
\hline
\end{tabular}




\begin{tabular}{|c|l|l|l|l|l|}
\hline $\begin{array}{c}\text { Number of } \\
\text { households } \\
\text { interviewed }\end{array}$ & 20 & 16 & 13 & 12 & 12 \\
\hline
\end{tabular}

In-depth interviews with heads of households aimed to gather opinions, facts and stories from expert 'insiders', and provided the most detailed and personal insights. In total, 73 household interviews were conducted in Spanish- one with each household head during each visit, lasting approximately one hour each. All interviews were conducted in a relaxed manner in the respondent's home so they felt comfortable to openly share experiences (Flick 2009). In addition, during the 54 days spent in Ingenio, extensive direct observation, and nonhousehold interviews were conducted. This included informal conversations with neighborhood residents on general matters (including home) that occurred naturally - what Barbour (2014, p 156) calls "incidental ethnographic encounters" (Luton 2015). This also involved meeting local officials from Toa Baja Municipality (e.g. the Mayor), local government officials (e.g. Head of Planning, Head of Community Affair, and Head of Public Works), and international and local NGOs, as well as the collection of secondary data, such as existing local government response and recovery plans. Interviews were recorded and both researchers took extensive notes during and after interviews, observations and field visits.

\section{Findings and discussion}

\section{A. Post disaster: Changing conditions beyond the household}

During the 12 months of data collection, several events and activities, which are typically observed in post disaster contexts across the world, took place (see Figure 1). These processes broadly refer to: distribution of relief aid and financial support from external actors; recovery support activities from neighbouring households and kin; the temporary closure and disruption of public assets e.g. electricity and water supply; and price fluctuations in local markets. Many of these events and activities were largely beyond the control of households; yet they directly affected household recovery, and people's sense of home.

In the following sections we critically discuss how these changes in the environment - which are observed in post disaster contexts, globally - impact on households' sense of home. In structuring our analysis this way, our article can further understanding of how people's sense of home is affected in post-disaster contexts in other parts of the world. Although we present our results chronologically, we are not suggesting that the timeline of the changing events and activities in Puerto Rico are universal. The distribution of relief aid may take place during different times, or public services may be restored much earlier than our case. Nevertheless, it is the influence of these changing events and activities on home that is most interesting to us, and which can guide research in other geographical contexts.

Figure 1 Changing conditions beyond the household scale, following initial disaster impacts MONTH AFTER HURRICANE

\begin{tabular}{|r|r|r|r|r|r|r|r|r|r|r|r|}
\hline 1 & 2 & 3 & 4 & 5 & 6 & 7 & 8 & 9 & 10 & 11 & 12 \\
\hline
\end{tabular}




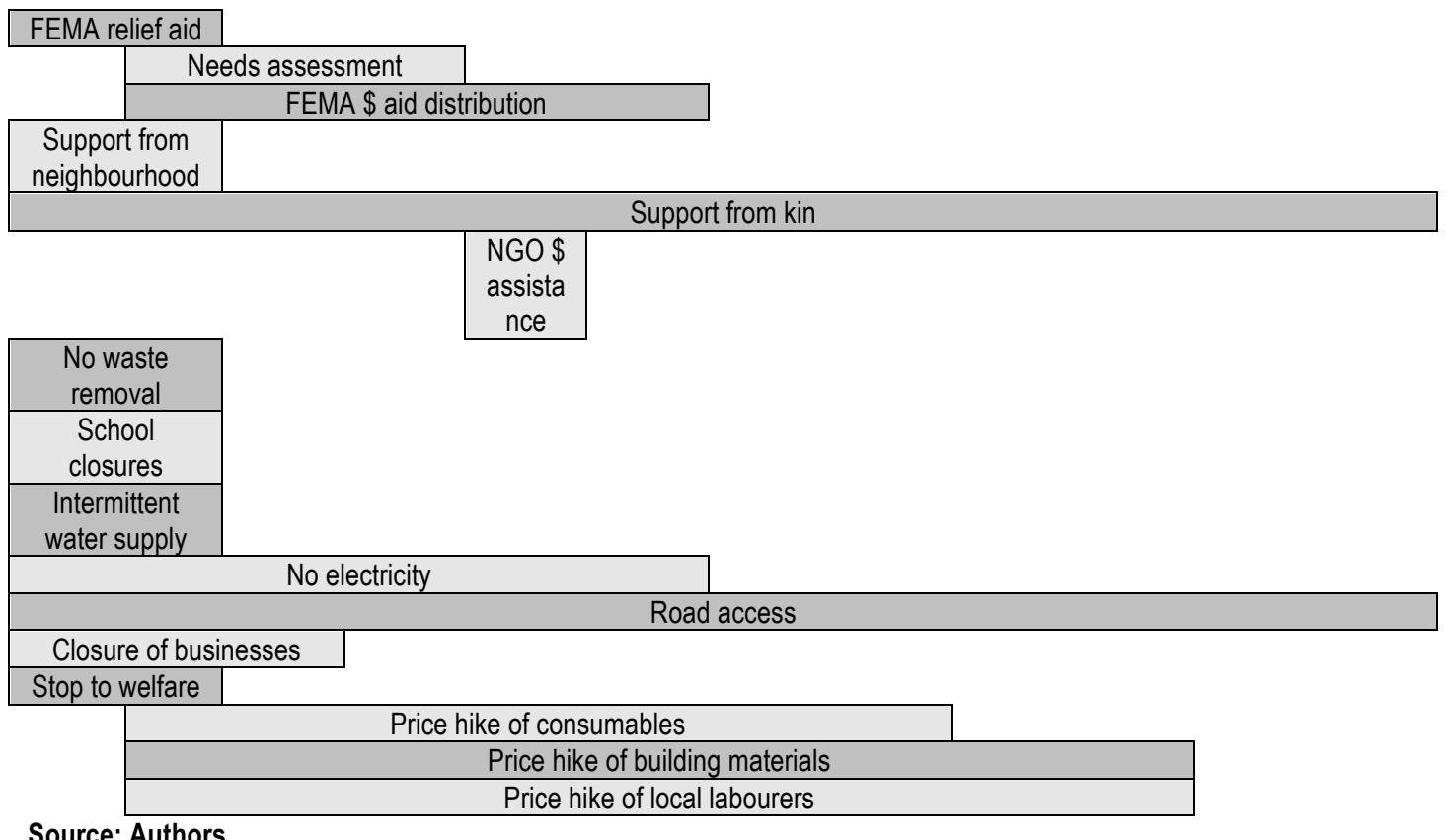

Basic public services were severely interrupted in the immediate aftermath of Maria. Solid waste removal services collapsed and were only fully restored five weeks after the hurricane. In the interim, the streets outside houses were lined with large piles of water-damaged furniture and other items that households had discarded following the hurricane. This attracted large numbers of cockroaches and rats that spread life-threatening diseases such as leptospirosis. Schools were completely closed during the initial two months, and only reopened in late November 2017. Water was sporadically piped to houses approximately three or four days a week for the initial six weeks, but was fully restored to normal working order by mid-November. Finally, the power grid across Puerto Rico was severely damaged, and households in the case neighborhood were left without electricity for almost six months.

Actors external to households became prominent in the neighborhood following the hurricane. International and domestic non-governmental humanitarian organizations (NGOs) were heavily present, handing out food and water during the initial six weeks. These groups included well-known international organizations such as the Red Cross, as well as smaller local Puerto Rican organizations, and missionary groups that arrived from the United States. The presence of these humanitarian organizations significantly scaled back by the third month after the hurricane, with only three case households receiving food and water aid at this time. By the seventh month after the hurricane, people said that food and water aid had completely ended,

"At first it was chaos. There were people from all over. Different organisations, handing out water and food. It was unbelievable, you should of seen it. Journalists and allsorts were here. But now it's all dried up, we don't see any aid now. They all left, so now we're alone". 
Kinship ties ${ }^{2}$, and other households within the neighborhood were particularly active, helping case households to remove debris and clean houses during the initial three weeks. However, recovery support from neighborhood households was minimal by the sixth week after Maria, illustrated by one woman,

"at first people were helping each other, but now it's back to the way it was before Maria. People are looking after themselves now. That's how people are around here. People just keep to themselves normally - we say hello and morning, but it's not a close knit community".

In contrast, support from kinship actors living within and beyond the neighborhood remained prominent throughout the 12 months of research. "We help each other as we can, you understand?... We help amongst ourselves and how we can like that... the dynamic is good". Initially, this came in the form of cleaning houses, and collecting aid for one another. In the medium term, kinship actors provided households with financial assistance, donated furniture and access to petrol-fueled generators that were privately bought. Kinship actors also provided temporary shelter for $90 \%$ of households during the initial month. This dropped to $75 \%$ by month six; however, $30 \%$ of case households were still temporarily living in the houses of their kin 12 months after the Hurricane.

Household needs assessments were carried out by FEMA between months two and three after the hurricane. This involved door to door visits by FEMA representatives. These assessments focused on the physical damage to the structure of houses, rather than loss and damage to household items and furniture, or the impacts on mental health, or emotional well-being. Therefore, households with minimal to no structural damage did not receive financial or technical support, despite experiencing significant material losses and aesthetic damage to the house. Financial support from FEMA was distributed to households between three and six months after the hurricane. However, the amount of financial assistance was significantly less than what households had applied for in all cases,

"500 dollars is not enough; not near enough aid for the house, to put it back again. So, we're using some of our savings and saving little by little".

Also, $50 \%$ of FEMA applications were rejected because households were unable to provide sufficient proof of home ownership according to FEMA regulations. Additional financial assistance of US $\$ 1500$ was provided by the Jennifer Lopez Foundation to $70 \%$ of households in March 2018 - five months after the hurricane.

As with other small island developing states, Puerto Rico is affected by its dependence on imports and the high costs associated with such imported commodities (Briguglio, et. al., 2009). U.S.A. policies have also had direct

\footnotetext{
${ }^{2}$ Kinship actors are blood relations and other individuals related via familial ties e.g. Sister in Law
} 
impacts on imported goods brought to the Island, further increasing the costs for all goods transported to Puerto Rico and limiting trade (Abel et al 2012). Demand for construction materials increased dramatically in the months following the hurricane impact, further increasing the price of materials between months two and ten after Hurricane Maria. For this reason, the price of food and other consumables increased between two months and six months after Hurricane Maria.

\section{B. Un-making and making home after Hurricane Maria}

Following the initial impacts of Hurricane Maria, household members experience disconnection from their home, despite continuing to reside in their house. This displacement manifests in multiple ways, reflecting a disruption to the three components of home discussed earlier. Our longitudinal data allows us to reveal how and why feelings of home wax and wane during the first year after a disaster. We also demonstrate the ways in which women in particular experience a loss of home acutely during post-disaster periods. Our data reveals how and why households experience and move through multiple stages of home loss, as well as restoration of home. Importantly, these stages do not fit neatly within a reductive binary of 'home loss' and 'restoration of home'. In fact, we find that there is no complete loss of home, nor a complete restoration of a pre-disaster sense of home during the first year after Hurricane Maria. Rather, there are dilutions and transformations of home, and how people connect and feel belonging with their home.

\section{a. Disrupting the material and emotional home}

We deal here with the first component of Blunt and Dowling's critical geography of home. Home has a number of different elements relating to the material dimension, or the house itself: privacy, domesticity, intimacy and, most importantly for Rybczynski (1986), comfort. Hurricane Maria had adverse impacts on all of these elements. Initially, all case houses were left in an extremely unclean state. Many ground level houses were left with up to six inches of thick black mud covering the floor, and walls covered in black dirt, left by the floodwaters. Many first floor houses suffered significant water and wind damage to the house and household items. The smell of damp and dirt was a constant across all of the houses during the initial weeks after Maria. For several households, the smell of damp did not disappear for five months as it took this long for the walls to dry. Adding to this, were the huge volumes of garbage that occupied the neighborhood's streets, during the first six weeks after Maria - and which attracted rats and cockroaches that spread leptospirosis, as one woman noted, "cockroaches kill us, rats pose a threat to us".

Household members were extremely preoccupied with the dirt, damp, mold and garbage within and beyond their house, because of the health-related impacts, and the profound negative impact on subjective well-being. People consistently expressed a loss of pride in their home, and a feeling of shame about their living situation. Some participants expressed feelings of "disgust" when they were at home or walking in their street. During the relief aid efforts of local and international organizations, households consistently requested cleaning equipment rather than bottled water, illustrating the interconnectedness of the material and the emotional, 
"I couldn't stand looking at those disgusting, dirty black walls...it's not the way my kids should be living, it's not good for them... You should of seen my house before, it was so beautiful, with all of our little things and photos and everything. Now, the house feels so empty, look around (gesturing to the interviewer to look at the house)" one woman said.

Enhancing the material conditions of the house through cleaning and other acts contained within the realm of 'domesticity', a feeling of home was restored in some way. Further to this, 12 months after Maria, participants were asked to reflect on how government disaster recovery efforts must improve in the future. Participants were in consensus that more efficient removal of garbage as well as the provision of cleaning equipment was absolutely fundamental, because of the myriad ways that a lack of control over everyday domestic tasks within and beyond the house had on household members' subjective well-being and emotional connection to their homes.

Image 1: Piles of garbage and debris left on the streets

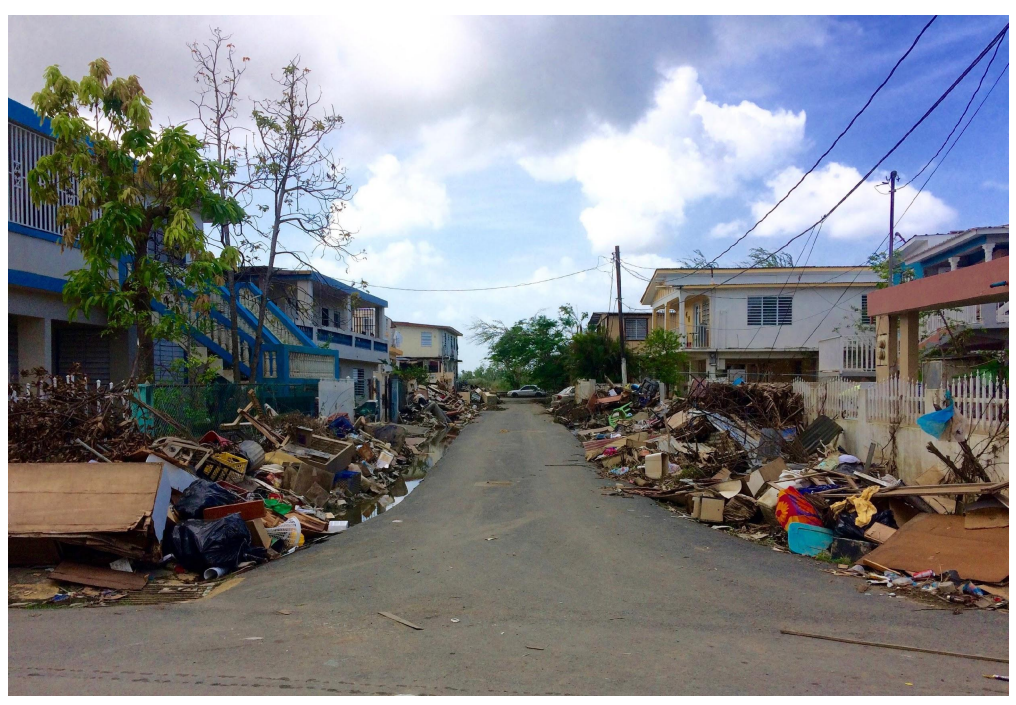

Source: Authors

The physical destruction of roofs, walls, furniture, and household items severely disrupts the material environment of homes. Due to loss or severe damage to everyday domestic items, people expressed that they did not recognize their home, and felt a sense of disconnection with their home. "Look around. This isn't my home. We've lost all of our things, everything gone'. During the initial two months after the hurricane, many houses were completely absent of everyday items such as sofas or dining tables. These items provided comfort, defined as feelings of ease and relaxation (Rybczynski 1986). They also functioned as objects that express the personal tastes, style, and aesthetic preferences of people. As such, participants complained of feeling uncomfortable in their homes, as well as losing pride in their home. Through these changes in the material environment of homes, household members expressed a sense of alienation from their home. This was most acute during the initial two months after Hurricane Maria, when many houses were dirty and absent of everyday 
cultural objects discussed above. Yet, a sense of emotional disconnection, feelings of discomfort and a loss of relaxation time within the home remained for many households during the entire 12 months of data collection. The prolonged and adverse impacts on home were due to the material impacts of the hurricane, as well as the disruption to daily home-making activities, discussed later in the paper.

Building on this, household items such as a sofa, television, or family photographs are not just physical artifacts. Rather, and reflecting a critical geography of home approach, these items function as cultural objects that create and consolidate people's identity within their home, and establish people's sense of emotional belonging as a result of the memories that are embedded within them (Blunt and Dowling 2006; Tolia-Kelly 2006). As one man shared, "My wedding photograph, it's my only one is ruined, gone. My wife is absolutely devastated". Some households received donated furniture, such as a sofa or dining table from relatives, friends or missionaries from the U.S.A during the first two months after Maria. Though this furniture served a practical function, many people expressed discomfort and feelings of unhomeliness because these items did not reflect their personal tastes and style. Blunt and Dowling (2006) also argue that the viewing and display of family photographs enables people to create a sense of homeliness, a material environment that felt homely. Photographs also allow household members to feel connected to family members and friends in other places and in the past, and to take pride in displaying their family achievements and events such as weddings and christenings. However, with the loss or damage of family photographs, many people expressed a deep sadness that their memories had been taken from them, and thus a loss of 'homeliness'.

Our data shows that households significantly value the restoration of the materiality of the home as a means to regain the emotional dimension of home, something which is largely overlooked in disaster recovery policy and literature. The speed at which households replace the cultural objects that consolidates their sense of selfidentity and agency (Dupuis and Thorns 1998), or what Somerville (1992) refers to as their ontological security, was unequal across households. Five case households invested in sofas and/or a television, and/or a dining table, before permanently fixing damaged roofs. Informal conversations with other residents also confirmed this behavior was not uncommon across Ingenio. The choice, placement and use of these objects were a fundamental process of home-making during the 12 months after Hurricane Maria. Several interviewees commented that buying a new sofa and having the ability to spend time sitting in comfort added a much missed feeling of "normality", "peace" and re-establishment of a "normal rhythm" to days. within the home, suggesting a positive effect on subjective well-being. Outsiders, and disaster risk managers in particular, may view the purchase of a sofa before fixing a roof as irrational. Yet, if we explore this behavior through the lens of 'home', and people's desire for comfort and pride in their home, we can begin to fully appreciate and understand such behaviors.

Baxter and Brickell's notion of home 'unmaking' (2014) is useful here. They articulate the concept as "a critique of the centrality of homemaking in literatures on home" (2014: 134), and attending to the ways that homes are 
unmade to then be remade in post-disaster contexts is important in this paper. Baxter and Brickell stress the importance of temporality in home unmaking, as processes of unmaking and making "signify change and the passing of time" (2014: 140). As has been discussed above and as is woven throughout the empirical examples discussed in this paper, the temporal experience of the loss and rebuilding of both the material and intangible resources of home are framed temporally. The desire and ability to return to the "normal rhythm" of life following the Hurricane was influenced partly by the prolonged state of uncleanliness following the disaster, as discussed above. The unmaking of home in this case, then, was hugely influenced by inaction on the part of the State, as six weeks after the Hurricane, there was still garbage in the streets, and the smell of damp in many homes. The proactive process of home-making, then, was hindered significantly by wider structural factors.

All case households experienced difficulties accessing and/or purchasing household materials to recover the material environment of the home. This was not simply because households lacked economic income - though this was an important element. Rather, between months two and ten after Hurricane Maria, it became difficult for households to purchase items such as doors, window frames and tin roofing, because demand outstripped the production and supply of these products,

"we had to order the door customised because there are none at the hardware store. I mean, the sizes that they have are standard and does not work for me, so we had to have them customised and now they told me in three more months they can deliver them...so right now we're using some material, just hanging it over the door. It's not great, but it will do for now"

Therefore, many households left moldy and dirty doors and windows hanging for up to ten months. As such, the restoration of home is delayed by processes external to the household, which added to households discomfort and disconnection with their home, discussed above. For other households, fabric was draped over the doorway of bedrooms; however, people explained that their bedrooms no longer felt like private a space. Kellett (2005) identifies that a bedroom does not only signify a place to sleep, but the ability of individuals to physically demarcate their lives as independent from the rest of the household - to provide people with a sense of privacy. Yet, this was significantly compromised for months following Maria.

For households that moved to temporarily live in the houses of other kinship-related households - some for as long as the entire 12 months of data collection - clutter also impacted on how people experienced home. Roster et al (2016) define clutter as an overabundance of material possessions that collectively create disorderly and chaotic home environments. During the temporary living arrangements described above, the volume of possessions become excessive. For example, it was typical that living areas functioned as bedrooms for family members during temporary living arrangement. Bedrooms became storage spaces, and it was usual for rooms to be cluttered with piles of boxes of household items. Reflecting research by Frost et al (2012), clutter interfered with household members' ability to carry out everyday home-making activities, particularly cleaning and 
maintaining the order of the home. Instead of creating a sense of connectedness with home, clutter exacerbated people's disconnectedness with home and compromises dimensions of homeliness. In these ways our research shows that, in Ingenio, clutter functioned as antagonistic to the normally positive benefits and consequences of home for subjective well-being.

Our longitudinal data shows that, during the initial six weeks after Maria, people found it difficult to describe and think about home. When interviewees were asked, "how will you rebuild your home? What will it look like?" people struggled to find the words. Households that had experienced the most severe physical and material damage to the house found it particularly difficult to imagine living in a homely, comfortable and beautiful home, because it seemed so far removed from their current experiences. The extent of the physical damage to their houses and the impact of this on their feelings of 'at-homeness', ruptured households' ability to imagine a home in which they would once more be able to "bring some space under control" (Douglas 1991: 289), and create a comfortable, 'homely' environment. The intricate relationship between the material and the emotional is stark here. Interestingly, we also found that people's ability to imagine how their house would look aesthetically, became more elaborate over the research period. During the initial three months after the initial impact of the Hurricane, we asked participants "what will your house look like when recovered?" People typically focused on the restoration of the physical structure of the house - the bricks and mortar, and the cleanliness of the house "I want it [the house] to be like it was, before Maria." Six months and onwards after initial impacts, however, responses were peppered with reference to interior décor, including the colour of paint, decorative finishing such as family photographs, lighting fixtures and the placement of trinkets and ornaments. In other words, people began to imagine how they would re-establish their emotional connectivity to their home, as well as consolidating their identities and agency within their home.

In addition to this, the financial needs assessment carried out by FEMA, between six weeks and three months after Hurricane Maria, resulted in only $50 \%$ of households receiving federal financial assistance. We find that the distribution of financial aid is a bureaucratic process that is unequipped to recognize locally and culturally specific living arrangements - a phenomenon that has been observed in multiple disaster recovery contexts (Tafti 2015). For instance, households were unable to provide legal proof of home ownership, despite many households living in their house for multiple decades. Commonly in the global south, home ownership belongs to a relative of the household head (Gilbert 2008). However, post-disaster it can be difficult for households to provide this information because the homeowner may have died, or contact may have been lost, or the homeowner is living elsewhere and cannot find the necessary documents, as we see with this quote

"Then, what happens is that the house does not have a title deed...I talked with my dad, my dad made a sworn declaration [to FEMA] that I have always lived here... and with all that we went to them, but it was still rejected...they really do not uderstand how people live around here. The whole process makes no sense" 
The combination of physical damage to the house and the lack of financial support further caused a rupture in the ability of households to imagine their homes in the future. The lack of financial support and on-going existence within a damaged house also disrupt the daily home-making activities taking place within the domestic sphere. This is discussed in more detail below.

\section{b. Disrupting daily home-making activities}

Everyday activities and routines are a critical component in the production of home. However, these practices were significantly transformed by the impacts of Hurricane Maria, most noticeably during the presence of humanitarian organizations, and whilst electricity was unavailable. This challenged home as a place of comfort, and served to 'unmake' peoples' active engagement and production of home (Baxter and Brickell 2014). Gender is a critical differentiating factor, as home-making practices in Puerto Rico position women as mothers, and as primarily responsible for the domestic sphere, which reflects global trends (Basu 2018). The gendered domestic division of labor results in women taking primary responsibility for the day-to-day running of home and the creation of a 'home-like' environment. These tasks include cooking, cleaning, washing, shopping and caring for children. Following Hurricane Maria, such daily and routine home-making activities are significantly temporally transformed, and in ways that adversely burden women.

Previous research on women in post-disaster contexts suggests that women take a 'lead role', and through an increased involvement in the maintenance and recovery of households they become empowered (Alam and Rahman 2017). In line with Drolet et al (2016) our research challenges this notion of women's empowerment, as our research suggests that gender inequalities are temporarily exacerbated in post-disaster settings because women are further burdened with home-making activities and/or experience a loss of economic power within the home. Our understanding of women's empowerment reflects a process that addresses the embedded structural gender inequalities that pre-date a disaster - which does not occur in the Puerto Rico case.

Home making relies on the agency of its occupants (Douglas 1991). However, for many people, and women in particular, home making was stripped away as a result of the impacts of the Hurricane. Women acutely felt this during the first four weeks after Hurricane Maria, when households were largely reliant on food and water aid from local and international aid organizations. As such, women's role as the provider of meals was suspended, and replaced with bi-weekly trips to pick up pre-prepared ready meals from relief distribution points. Women therefore spent less time preparing meals in the kitchen - a fundamental part of women's home-making activities. A number of scholars in migration studies examine processes of home making and experiences of temporal rupture of refugees or those living in liminal situations (Brun 2015; Bloch 2000). The difficulties of conducting everyday home-making practices in the context of an uncertain future, as is the case for those in the asylum system (Bloch 2000; Webber 2018), or living in protracted refugee situations (Hammond 2004), arguably necessitate a temporal lens. Considering the emotional element of home requires that we understand the temporal layers of home as an enmeshing of past, present and future, and the ways that home-making practices 
indeed structure the process of making home over time.

Absent from Blunt and Dowling's critical geography of the home is an understanding of temporality. If we understand that homes are made (just as they can be unmade), then we also understand that homes are made over time (Baxter and Brickell 2014). We therefore contribute to this body of work by including a temporal framework in our analysis. The need for a temporal understanding of home, then, is twofold. Firstly, in the intersection between disaster studies and home scholarship, the temporal framework of recovery is vital, hence why the approach taken here is longitudinal. This approach facilitates the understanding of how the recovery of the home takes place over time, as it is supported (or indeed not) by the State. Secondly, the temporal dimension of the everyday is vital to incorporate here, as the time taken for normal everyday activities such as cooking and cleaning are greatly affected by disasters, and thus the temporal structuring of the everyday shifts drastically. Alheit (1994) draws a distinction between 'everyday time' which is routine and cyclical and 'lifetime' which comprises the biographical coherence, arguing that life is lived in the entanglement between the two. The setting of biographical agendas; or the emotional element of home, is important for safeguarding a sense of continuity, in turn important as a means to preserve identity when confronted with events which disrupt everyday life. This is evident in the analysis presented here, as individuals imagine what their homes will look like in the near future in a bid to safeguard this sense of emotional consistency of the home. This is discussed in greater detail in the analysis below.

The lack of electricity for six months had a profound impact on women's home-making activities. One woman commented that she no longer recognized her life as a result of her inability to carry out her usual everyday home-making practices, "everything takes so much longer, it's such a strain to try and get everything done now. Before Maria it was so much easier." Washing machines, refrigerators, lighting, ovens and food processors, which make household duties less time and labor intensive, were no longer available after the Hurricane. The notion of the 'modern' and 'efficient' house worker was significantly disrupted. For example, women resorted to hand-washing clothes with improvised devices (see image 2), which they referred to as "back-breaking" to complete. The temporal shift of everyday home-making practices in a post-disaster context is stark here. Furthermore, if households were to eat fresh fruit, vegetables, meat and other food products, shopping became a daily rather than a weekly duty. Additionally, once NGOs had left Ingenio two months after Maria, many women started to use small gas-fuelled camping stoves to cook. This transfers agency back to women, who then took control of cooking - a key home-making activity. However, cooking on small stoves was highly inconvenient as it significantly increased the amount of time women spent preparing meals (see image 3 ). Adding to this burden, many women had to cook for more people than pre-Hurricane Maria, because households temporarily restructured to include extended families. 


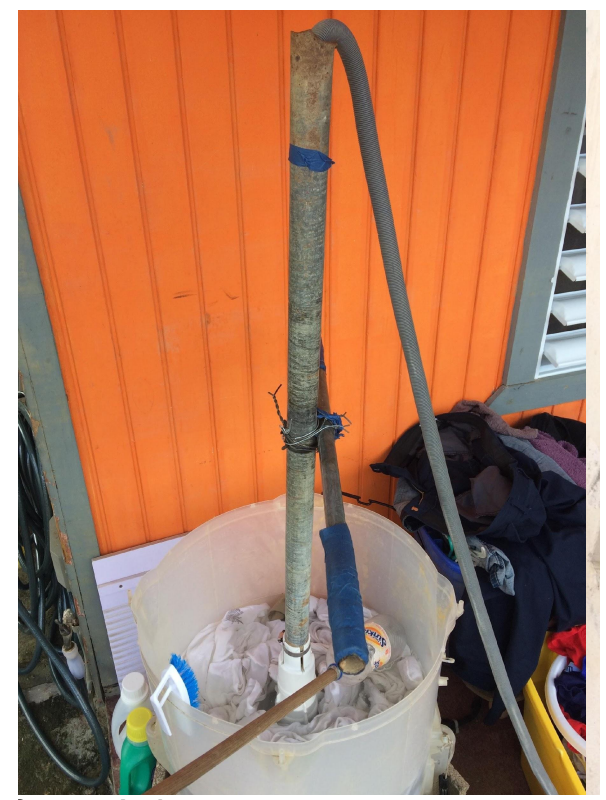

The role that spare time played in home-making practices was also adversely transformed following the impacts of Maria. In particular, television was an important domestic technology as many households watched TV at home and incorporated TV into domestic life prior to the hurricane. For most households, the TV occupied a central home-based activity during people's spare time, whereby household members would congregate to spend time together. Similar findings were noticeable in relation to computers and the Internet. Routine activities like children completing their homework with use of the Internet, or spending their free time browsing and exploring the Internet was no longer possible. Children were left to find new activities to occupy their spare time. Our initial assumption was that children might now start to spend more time playing outdoors. However, interviews revealed that many parents prevented their children playing outdoors, "the children are bored. They don't want to be inside all the time, but it's not safe." one woman told us. Initially this was due to the dangers of catching disease from the garbage lining streets, but later it was because parents did not think it safe for their children to play outside in the dark as rumours began to spread about men attempting to abduct children.

Ultimately, these decisions increased the time women spent on childcare duties.

\section{c. Transformation of the multi-scalar home in disaster contexts}

Blunt and Dowling's (2006) third component of home relates the ways in which home can register at different scales - streets, neighborhoods, public spaces, cities, and nations. Often a sense of home or meaningful dwelling involves the residential house and neighborhood simultaneously (Hawkins and Maurer 2011). The activities that make a home stretch beyond the house and incorporate the extra-domestic-neighboring, shopping, home-financing, family and friendship networks (Moss 1997). The scale of the State is thus intricately linked with the scale of the house and the neighborhood. In this way, home expands beyond the parameters of the house not only in the ways that households construct their sense of belonging in relation to multiple scales (e.g. the house, the neighborhood), but also in the ways that action taken at the scale of the State materially 
affects the ways that households construct their belonging, as individuals are stripped of the control they are able to exercise over the space of the house (Douglas 1991; Hammond 2004). As discussed earlier on in this paper, State responses post-disaster in this context are shaped by the imbalance of power in the relationship between Puerto Rico and the United States more broadly as a colony. This response impacts directly upon the recovery of both material and emotional geographies of home.

The lack of water for instance meant that households adapted by using bottles of aid water to have quick showers and hand wash small amounts of clothes. When water was available households often spent this period cleaning the house or storing the piped water in buckets to clean the house and removing dirt and mud left by floodwater. Thus we can see once more the ways in which decisions over how time is spent in the home are dictated by the lack of resources available, as everyday activities take a lot longer than the pre hurricane period. For instance, many people described the ways in which the rubbish on the street - which was still not cleared up two months after the Hurricane - led to feelings of "disgust" and lack of pride in the neighborhood, emphasizing the often intimate relationship between the house and the neighborhood more widely.

In Ingenio, the streets function as an extension of home, offering neighborhoods for children, and less work for women in terms of childcare duties. In this way, the street takes on the characteristics of home, blurring the boundaries between the private house and the public spaces beyond it (James and Duncan, 2004; Hammond 2006). However, as outlined above, as a result of interruptions to waste removal and electricity services children spent less time playing in the street. As such, the scale of home for many children became reduced to the house rather than the neighborhood. This was particularly so during the initial six weeks after Maria when parents were preoccupied with children catching disease from garbage, and during school closures. Once garbage was removed, and schools reopened, the children's scale of home once more expanded beyond the physical boundaries of the house. Yet, the children's scale of home continued to be housebound during the evenings, when street lighting was still unavailable. Only once the public electricity was restored in March 2018 did children's scale of home return to what it was before Hurricane Maria, expanding once more to the scale of the neighborhood.

The relationship to the surrounding neighborhood was drastically altered as a direct outcome of lack of sufficient State support. The absence of street lighting resulted in a feeling of insecurity and fear in a space that previously was closely linked to the idea of home. In this way, post-disaster, we can understand that the spaces bound up in understandings of 'home' can become unrecognizable and fall outside of the sphere of homeliness until a return to normality occurs, in this case through the return of street-lighting. Interestingly, however, the relationship with the neighborhood shifted over time following the Hurricane. There was initially an increase in connection with neighborhood residents, for approximately three weeks after the hurricane, as the loss of the physical house was replaced with greater connection and belonging in the community. During this time the public and private scales of home became visibly enmeshed, as households relied on NGOs and the local community for food and other 
forms of support. However, upon the departure of the NGOs, eight weeks after the hurricane, this connection became less visible, as households became more oriented towards the scale of the house and the household. In this way, the public and private spheres became more boundaried. We argue that while Humanitarian organizations do not replace a sense of home, they can offer distraction from the loss of home. This distraction, however, is not sufficient or sustainable, and State support in enabling communities and neighborhoods to return to their pre-disaster State is imperative for the return to normality and to facilitate the full agency of households. ${ }^{3}$

\section{Conclusion}

At the beginning of this paper we identified a methodological and conceptual bias in disaster research. That is, to focus on disaster impacts and recovery of tangible and quantifiable resources. In light of this, we theoretically focused on home in order to explore the role that subjective intangible resources and emotional geographies of home (Blunt and Dowling 2006) play in post-disaster contexts, with a focus at the household scale. The link between home and disasters has to date been investigated primarily in relation to displaced people, yet, there is little research on how people experience and navigate their sense of home when they remain in place. Through this approach, our research in Puerto Rico makes several contributions to disaster studies, as well as sustainability studies and development geography more broadly.

First, our focus on the concept of 'home' using qualitative longitudinal methods enriches our understanding of how people socially and culturally experience the impacts of disasters over time. Specifically, we demonstrated that the social characteristics of intangible resources are challenged, transformed, and/or exacerbated in different ways, and at different times, in post-disaster contexts. This can have adverse impacts on household members particularly women in our case. Places become both homely and unhomely at the same time. Furthermore, people experienced feelings of belonging and attachment, alienation and detachment, which waxed and waned over the initial 12 months after initial hazard impacts. These impacts on subjective well-being and mental health, are in line with work on how climate change is negatively affecting feelings of place attachment by disrupting hunting, fishing, foraging, trapping, and traveling, and changing local landscapes (Wilcox et al 2012). We identified a distinct lack of external support in recovering emotional geographies of home, as the focus of aid and recovery programmes was geared disproportionately towards the material geographies of home. Aid and recovery programmes therefore need to support household recovery of subjective intangible resources which reinstate these emotional geographies and senses of home. In the case of home, this may be through the provision of financial assistance for the restoring of the material components of home, which can consolidate identity and bring comfort.

Second, our longitudinal research also shows that in the aftermath of disasters, the performance and behaviour of external actors such as the State and NGOs, significantly shape how intangible resources are transformed, as

\footnotetext{
${ }^{3}$ To read a graphically illustrated version of this research, please see Sou, G. and Cei Douglas, J. (2019). After Maria: Everyday recovery from disaster University of Manchester, U.K. (a graphic novella).
} 
well as households' capacity to maintain emotional geographies of home. The complex dynamics of the multiscalar nature of home are obvious here. The decisions and performance of external actors at the scale of the State challenge and subvert people's agency to maintain a sense of home in the context of remaining in place post-disaster. This is useful for researchers and practitioners working in other contexts because the decisions and performance of external actors in the Puerto Rico case are typical in post-disaster contexts in the global south. As such, our paper sheds light on how emotional geographies of home are navigated and experienced in other areas post-disaster.

Third, we observed how and when - over a one-year period - intangible resources facilitate and guide household disaster recovery. That is, disaster-affected households significantly value the recovery of both the material and emotional components of home in the aftermath of a shock, such as a 'natural' disaster. This is due to the feelings of alienation and emotional detachment that a rupture of these components of home can cause, as well as the adverse and tangible impacts that this loss can have on household members - particularly women in the case of home. For instance, the disruption to home resulted in a loss of spare time, and an increase in the labor and time intensity to complete daily household activities. As such, we conceptually and empirically demonstrate why it is important that disaster impacts assessment and recovery policies acknowledge and incorporate the recovery of intangible resources. This is vital if we are to ensure best practice, both at a State and NGO level.

We identify an absent temporal dimension of home, which Blunt and Dowling (2006) gloss over when outlining their three components of home: as material and emotional, as comprising of everyday practices and as multiscalar. As a result of the longitudinal element of our data, we observed how time and temporality shape how the three components of home are experienced in a post-disaster context. This was most strongly emphasised in the second component, regarding everyday home-making activities. As a direct outcome of lack of State support and the time taken to reinstate normal provision, the everyday tasks of home-making take a much longer time to complete, thus robbing women in particular of their agency in terms of dictating how their time is spent. This paper therefore introduces a temporal framework into our conceptualisation of experiences of and disruptions to 'home' in a post-disaster context. In this way, we were able to understand the ways in which home is experienced temporally as well as spatially. Developing an understanding of home as both spatial and temporal allows us to make two key recommendations. Firstly, that given the impact of disasters on the time taken to carry out the daily routines and practices, which comprise processes of home making, it is vital that normal resources such as electricity and water are reinstated as soon as possible. This would enable those living in a post-disaster context to regain control over both the temporal and spatial structure of their day (Douglas 1991). Secondly, that building an understanding of the ways in which both the material and emotional geographies of home take time to develop and to regain following a disaster, it is vital that external actors such as the State and NGOs support the swift reinstatement of both these key and deeply intertwined components of home. 
It is also imperative that further research and policies in the fields of disasters, sustainability and development, identify and operationalize intangible resources, such as home. Absences of this kind can result in scholarship and policies that are incomplete, because the impacts and experiences of disaster-affected people are misrecognised and underestimated. To acknowledge the role of intangible resources is to directly challenge the skewed and reductive hierarchies of what counts as a disaster loss. This is an innately political endeavour because it aims to develop strategic decision-making, from preparedness to recovery that is more suitable and thereby sustainable for disaster-affected populations.

\section{Acknowledgements}

We would like to thank every single person who kindly gave their time to speak to us in Puerto Rico - we are very grateful. Thank you to the anonymous reviewers who helped us make this a much stronger paper.

\section{Funding sources}

The University of Manchester Business School and the Economic and Social Research Council funded this research.

\section{References}

Abel, J., Bram, J., Deitz, R., Klitgaard, T., \& Orr, J. (2012). Report on the competitiveness of Puerto Rico's economy. New York City, NY: US Federal Reserve Bank of New York.

Al-Ali, N., \& Koser, K. (2002). New Approaches to migration: transnationalism and transformations of home.

Alam, K., \& Rahman, M. H. (2017). The Role of Women in Disaster Resilience. Handbook of Disaster Risk Reduction and Management (Madu CN and Kuei C Eds.). World Scientific Press, New York, 697-719.

Basu, A. (2018). The challenge of local feminisms: Women's movements in global perspective. Routledge.

Baxter, R., \& Brickell, K. (2014). For home un-making. Home cultures, 11(2), 133-143.

Bloch, A. (2000) 'Refugee settlement in Britain: the impact of policy on participation'. Journal of Ethnic and Migration studies. 26(1), pp. 75-88 [online source] Available from:

http://www.tandfonline.com/doi/abs/10.1080/136918300115651 (26/11/2016)

Blunt, A., \& Dowling, R. (2006). Home (Key ideas in geography). Abingdon: Routledge.

Blunt, Alison Varley, Ann. (2004) Geographies of home. Cultural Geographies, (11) 3 - 6

Bond, A., Morrison-Saunders, A., \& Pope, J. (2012). Sustainability assessment: the state of the art. Impact Assessment and Project Appraisal, 30(1), 53-62.

Brickell, K. (2012). 'Mapping'and 'doing'critical geographies of home. Progress in human geography, 36(2), 225244.

Brun, Cathrine and Ragnhild Lund. 2008. "Making a Home during Crisis: Post-Tsunami Recovery in a Context of War, Sri Lanka." Singapore Journal of Tropical Geography 29(3): 274-87

Brun, Cathrine and Fábos, Anita.(2015) Making Homes in Limbo? A Conceptual Framework. Refuge 31(1) 5 - 18 
Chamlee-Wright, E., \& Storr, V. H. (2009). Club goods and post-disaster community return. Rationality and Society, 21(4), 429-458.

Csikszentmihalyi, M., \& Halton, E. (1981). The meaning of things: Domestic symbols and the self. Cambridge University Press.

Douglas, M. (1991). The idea of a home: A kind of space. Social research, 287-307.

Drolet, J., Dominelli, L., Alston, M., Ersing, R., Mathbor, G., \& Wu, H. (2015). Women rebuilding lives postdisaster: innovative community practices for building resilience and promoting sustainable development. Gender \& Development, 23(3), 433-448.

Duncan, J. S., \& Lambert, D. (2004). Landscapes of home. A companion to cultural geography, 382-403.

Dupuis, A., \& Thorns, D. C. (1998). Home, home ownership and the search for ontological security. The sociological review, 46(1), 24-47.

Easthope, H. (2004). A place called home. Housing, theory and society, 21(3), 128-138.

ECLAC, 2014. Handbook for Disaster Assessment. Economic Commission for Latin America and the Caribbean.

Elkington, J. (2006). Governance for sustainability. Corporate Governance: An International Review, 14(6), 522529.

Ellsworth-Krebs, K., Reid, L., \& Hunter, C. J. (2019). Integrated framework of home comfort: relaxation, companionship and control. Building Research \& Information, 47(2), 202-218.

EM-DAT (n.d.). The international disaster database. https://www.emdat.be/database (accessed November 2 2018)

FEMA (2017) Hazus: Estimated Damage and Economic Losses Puerto Rico, United States.

https://data.femadata.com/FIMA/NHRAP/Maria/HurricaneMaria_ARA_InitialRun.pdf (Accessed October 18 2018)

Flick, U. (Ed.). (2009). The sage qualitative research kit: Collection. SAGE Publications Limited.

Frost, R. O., Steketee, G., \& Tolin, D. F. (2012). Diagnosis and assessment of hoarding disorder. Annual review of clinical psychology, 8, 219-242.

Gentle, N., Kierce, S., Nitz, A., 2001. Economic costs of natural disasters in Australia. Aust. J. Emerg. Manage. 16 (2), 38-43.

Gilbert, A. (2008). Slums, tenants and home-ownership: on blindness to the obvious. International Development Planning Review, 30(2), i-x.

Hallegatte, S., \& Przyluski, V. (2010). The economics of natural disasters: concepts and methods. The World Bank.

Hammond, L. (2004). This place will become home: refugee repatriation to Ethiopia. Cornell University Press.

Hawkins, Robert and Katherine Maurer. 2011. "You Fix My Community, You Have Fixed My Life': The Disruption and Rebuilding of Ontological Security in New Orleans." Disasters 35(1): 143-59

Katz, Cindi. 2008. "Bad Elements: Katrina and the Scoured Landscape of Social reproduction." Gender, Place and Culture 15(1): 15-29. 
Kellett, P. (2005). The construction of home in the informal city. Critical Studies, 27, 22.

Kousky, C., 2012. Informing climate adaptation: a review of the economic costs of natural disasters, their determinants, and risk reduction options. Resour. Future Discuss. Pap., 12-28

Magee, L., Handmer, J., Neale, T., \& Ladds, M. (2016). Locating the intangible: Integrating a sense of place into cost estimations of natural disasters. Geoforum, 77, 61-72.

Mallett, S. (2004). Understanding home: a critical review of the literature. The sociological review, 52(1), 62-89.

Marcus, G. E. (1995). Ethnography in/of the world system: The emergence of multi-sited ethnography. Annual review of anthropology, 24(1), 95-117.

Massey, D. ([1994] 2001) Space, place and gender. Minnesota : University of Minnesota Press

Massey, D. (1992) 'A Place Called Home?', New Formations (17) 3-15.

Moore, J. (2000). Placing home in context. Journal of environmental psychology, 20(3), 207-217.

Massey, D. (1992). A place called home. New formations, 17(7), 3-15.

Morrice, Stephanie. 2013. "Heartache and Hurricane Katrina: Recognising the influence of Emotion in PostDisaster Return Decisions." Area 45(1): 33-9

Moss, P. (1997). Negotiating spaces in home environments: Older women living with arthritis. Social Science \& Medicine, 45(1), 23-33.

Neumayer, E., \& Barthel, F. (2011). Normalizing economic loss from natural disasters: a global analysis. Global Environmental Change, 21(1), 13-24.

Nowicki, M. (2014). Rethinking domicide: Towards an expanded critical geography of home. Geography Compass, 8(11), 785-795.

Nurse, L.A., R.F. McLean, J. Agard, L.P. Briguglio, V. Duvat-Magnan, N. Pelesikoti, E. Tompkins, and A.Webb, 2014: Small islands. In: Climate Change 2014: Impacts, Adaptation, and Vulnerability. Part B: Regional Aspects. Contribution of Working Group II to the Fifth Assessment Report of the Intergovernmental Panel on Climate Change [Barros, V.R., C.B. Field, D.J. Dokken, M.D. Mastrandrea, K.J. Mach, T.E. Bilir, M. Chatterjee, K.L. Ebi, Y.O. Estrada, R.C. Genova, B. Girma, E.S. Kissel, A.N. Levy, S. MacCracken, P.R. Mastrandrea, and L.L.White (eds.)]. Cambridge University Press, Cambridge, United Kingdom and New York, NY, USA, pp. 1613-1654.

Power, M., 2007. Organized Uncertainty: Designing a World of Risk Management. Oxford University Press, New York.

Porteous, D., \& Smith, S. E. (2001). Domicide: The global destruction of home. McGill-Queen's Press-MQUP.

Rapport, N., \& Dawson, A. (1998). Home and movement: a polemic. Migrants of identity: perceptions of home in a world of movement, 19-38.

Roster, C. A., Ferrari, J. R., \& Jurkat, M. P. (2016). The dark side of home: assessing possession 'clutter'on subjective well-being. Journal of Environmental Psychology, 46, 32-41.

Rybczynski, W. Home: A Short History of an Idea (New York: Penguin Books, 1986)

Schumacher, I., \& Strobl, E. (2011). Economic development and losses due to natural disasters: The role of hazard exposure. Ecological Economics, 72, 97-105. 
Smith, A. B., \& Katz, R. W. (2013). US billion-dollar weather and climate disasters: data sources, trends, accuracy and biases. Natural hazards, 67(2), 387-410.

Somerville, P. (1992). Homelessness and the meaning of home: Rooflessness or rootlessness?. International Journal of urban and regional Research, 16(4), 529-539.

Sou, G. (2014). Risk Perceptions and responses in disaster-prone cities of the Global South. PhD thesis, University of Manchester, Manchester

Sou, G. (2018). Mainstreaming risk reduction into self-build housing: the negligible role of perceptions. Climate and Development, 10(6), 526-537.

Sou, G. and Cei Douglas, J. (2019). After Maria: Everyday recovery from disaster University of Manchester, U.K. (a graphic novella).

Sparrow, B. (2017). A Territorial State: Geographic Expansion, the US Territories, and an "Introduction to American Politics". PS: Political Science \& Politics, 50(2), 492-496.

Sutton, D.E. (2001) Remembrance of repasts: an anthropology of food and memory. Oxford: Berg

Tafti, M. T. (2015). Housing assistance distribution after disasters: does it enable affected households to recover?. Environmental Hazards, 14(4), 361-377.

Thanurjan, R., \& Indunil P. Seneviratne, L. D. (2009). The role of knowledge management in post-disaster housing reconstruction. Disaster Prevention and Management: An International Journal, 18(1), 66-77.

Tolia-Kelly, D.P(2006) 'Ch. 2 Part III. A Journey through the Material Geographies of Diaspora Cultures: Four modes of environmental memory' in: Burrell, K. \& Panayi, P. (eds.) Histories and Memories: Migrants and their History in Britain. London : Tauris Academic Studies. pp. 149 - 171

Truffer, B., Murphy, J. T., \& Raven, R. (2015). The geography of sustainability transitions: Contours of an emerging theme. Environmental Innovation and Societal Transitions Volume 17, Pages 63-72

U.S. Census Bureau (2018). https://www.census.gov/ (accessed November 2, 2018)

Vecvagars, K., 2006. Valuing Damage and Losses in Cultural Assets after a Disaster: Concept Paper and Research Options, Estudios y Perspectivas series (LC/MEX/ L.731), Mexico City, ECLAC subregional headquarters in Mexico.

Vogl, S., Zartler, U., Schmidt, E. M., \& Rieder, I. (2018). Developing an analytical framework for multiple perspective, qualitative longitudinal interviews (MPQLI). International Journal of Social Research Methodology, 21(2), 177-190.

Von Peter, G., Von Dahlen, S., \& Saxena, S. C. (2012). Unmitigated disasters? New evidence on the macroeconomic cost of natural catastrophes.

Webber, R. (2018) "Picturing Home: exploring the everyday home-making practices of migrant, refugee and asylum-seeking women in Glasgow" PhD thesis, University of Leicester, Leicester

Willox, A. C., Harper, S. L., Ford, J. D., Landman, K., Houle, K., \& Edge, V. L. (2012). "From this place and of this place:" Climate change, sense of place, and health in Nunatsiavut, Canada. Social science \& medicine, 75(3), 538-547.

Yin, R. K. (2003). Case study research design and methods third edition. Applied social research methods series, 5. 
